Tropical Journal of Pharmaceutical Research March 2017; 16 (3): 494-500

ISSN: $1596-5996$ (print); 1596-9827 (electronic)

(C) Pharmacotherapy Group, Faculty of Pharmacy, University of Benin, Benin City, 300001 Nigeria.

All rights reserved.

Available online at http://www.tjpr.org

Original Research Article

http://dx.doi.org/10.4314/tjpr.v16i3.1

\title{
Preparation of Tradescantia pallida-mediated zinc oxide nanoparticles and their activity against cervical cancer cell lines
}

\author{
Cai-yun Li, Zheng-cheng Zhang*, Jing-yue Mao, Li-feng Shi, Ying Zheng and \\ Jia-li Quan
}

Department of Obstetrics and Gynecology, The 117th hospital of Chinese People's Liberation Army, Hang Zhou City,Zhe Jiang Province 310013, China

*For correspondence: Email: zhengceng3476@hotmail.com; Tel/Fax: 0086-571-87348682

Revised accepted: 14 February 2017

\begin{abstract}
Purpose: To synthesize zinc oxide nanoparticles (ZnO NPs) using Tradescantia pallida. (Commelinaceae) and determine their fluorescent and cytotoxic properties.

Methods: ZnO NPs were synthesized according to a simple protocol using T. pallida aqueous leaf extract (TPALE). Scanning electron microscopy (SEM) and transmission electron microscopy (TEM) were used to analyze the morphology of the ZnO NPs. X-ray diffraction (XRD) and Fourier transforminfrared spectroscopy (FTIR) measurements were performed to determine their crystalline nature and functional groups, respectively. Fluorescence spectroscopy was used to assess the photoluminescence properties of ZnO NPs. Upon confirmation of ZnO NP synthesis, cytotoxicity tests were carried out against HeLa cell line by 3-(4,5-dimethylthiazol-2-yl)-2,5-diphenyltetrazolium bromide (MTT) assay.

Results: The agglomerated ZnO NPs were rod-shaped and had a mean particle size of $25 \pm 2 \mathrm{~nm}$. Further, they exhibited good photoluminescence with correlation to ZnO crystals. MTT assay results indicated significant cytotoxicity against HeLa cervical cancer cell line.

Conclusion: A simple approach for ZnO NP synthesis based on TPALE has been developed successfully. The synthesized ZnO NPs demonstrate good luminescence properties and cytotoxicity against cervical cancer line.
\end{abstract}

Keywords: Commelinaceae, Cytotoxicity, Photoluminescence, Setcreasea pallida, Setcreasea purpurea, Tradescantia pallida, ZnO nanoparticles

Tropical Journal of Pharmaceutical Research is indexed by Science Citation Index (SciSearch), Scopus, International Pharmaceutical Abstract, Chemical Abstracts, Embase, Index Copernicus, EBSCO, African Index Medicus, JournalSeek, Journal Citation Reports/Science Edition, Directory of Open Access Journals (DOAJ), African Journal Online, Bioline International, Open-J-Gate and Pharmacy Abstracts

\section{INTRODUCTION}

Nanotechnology is one of the most versatile areas of current research and has wide-ranging applications. A number of toxic physio-chemical techniques, such as spray pyrolysis, gas-phase methods, chemical vapor deposition, electrochemical methods, and laser ablation techniques, have been introduced to synthesize nanoparticles (NPs) [1]. In this study, we focused on non-toxic-mediated synthesis of NPs based on plant extracts. Tradescantia pallida plants are mostly used as ornamental plants in Romania [2], but they are highly adaptable, particularly to shaded environments. Most researchers have used T. pallida root for histopathological studies [3]. Recently, a research group reported histopathological studies indicating that T. pallida can adapt to shade environments when calcium crystals are present [4]. Various researchers 
have focused on metal NP synthesis, but there are no results concerning $T$. pallida-mediated synthesis of metal NPs. In this study, we synthesized zinc oxide nanoparticles (ZnO NPs) using $T$. pallida aqueous leaf extract (TPALE). These $\mathrm{ZnO}$ NPs have a wide variety of applications, e.g., anti-microbial [5], cosmetics [6], anti-cancer [7], agriculture [8], optical [9], and electrical [10]. Currently, a number of researchers are interested in using $\mathrm{ZnO}$ NPs to diagnose medical disorders [11]. There have been a number of studies concerning photoluminescence and cytotoxicity studies of synthetic ZnO NPs [12-14].

\section{EXPERIMENTAL}

\section{Materials}

Zinc acetate was procured from Avra Laboratories, Hyderabad, India. HeLa cell lines were collected from the King Institute, Guindy, Chennai, Tamil Nadu, India. Methyl thiazolyldiphenyl-tetrazolium bromide (MTT, 3(4,5-dimethylthiazol-2-yl)-2,5-diphenyltetrazolium bromide) was obtained from AVRA Laboratories. Double-distilled water was used in all experiments with no purification.

\section{Preparation of plant extract}

T. pallida leaves were collected from the gardens of the 117th Hospital of the Chinese People's Liberation Army, Hang Zhou City. The leaves were dried in the shade for 4 days. Once dried, the leaf material was ground to a powder. Then, $30 \mathrm{~g}$ of the leaf powder material was immersed in $100 \mathrm{~mL}$ distilled $\mathrm{H}_{2} \mathrm{O}$ and placed in a water bath for $1 \mathrm{~h}$ at $60 \stackrel{\circ}{\circ} \mathrm{C}$. The solution was filtered, then the filtrate was stored in the refrigerator until needed.

\section{ZnO NP synthesis}

TPALE $(20 \mathrm{mg})$ was mixed with $1-\mathrm{mM}$ zinc acetate $(80 \mathrm{~mL})$ and placed in a water bath at 60 ${ }^{\circ} \mathrm{C}$ for $4 \mathrm{~h}$. The resultant solution was centrifuged for $30 \mathrm{~min}$ at $4,500 \mathrm{rpm}$. After centrifugation, a pellet was obtained and heated in a furnace at $350 \stackrel{\circ}{C}$ for $5 \mathrm{~h}$. Once the calcination process was completed, the powder samples were characterized as described below.

\section{XRD analysis}

X-ray diffraction (XRD) analysis (Model D8, Advance Powder X-ray Diffractometer, Bruker, Germany) and Fourier transform infrared (FT-IR) spectrum analysis (Jasco 6600, Oklahoma City, OK, USA) were used to identify the crystalline nature and functional groups of the synthesized ZnO NPs, respectively. The crystalline size of the $\mathrm{ZnO}$ NPs was calculated using Scherrer's relationship (Eq 1).

$D=k \lambda / \beta \cos \theta$

where $D$ is the particle size, $k$ is Scherrer's constant (0.94), $\lambda$ is the wavelength, derived from Bragg's equation ( $2 \mathrm{~d} \sin \theta=n \lambda), \beta$ is the halfwidth full-maximum, and $\theta$ is the diffraction angle.

\section{Morphological analysis}

Scanning electron microscopy (SEM, Hitachi 7100 , Tokyo, Japan) was used to determine the structure of the sample at a voltage of $100 \mathrm{kV}$. A Bruker 501 transmission electron microscopy (TEM) system, equipped with $\mathrm{X}$-ray microanalysis capabilities, was used to perform microstructural analysis of the powder. Energy dispersive X-ray spectroscopy (EDAX) was carried out with an Oxford Instruments X-act 10$\mathrm{mm}$ SDD (Philips, CM 200) (operating voltage range: $20-200 \mathrm{kV}$; resolution: $2.4 \AA$ A).

\section{Fluorescence studies}

Fluorescence spectroscopy was used to investigate the photoluminescence properties of the synthesized $\mathrm{ZnO}$ NPs. Fluorescence spectra were obtained using an F-7000 FL spectrophotometer (Hitachi Perkin-Elmer, Bengaluru, Karnataka, India). Cell viability was calculated as in Eq 2.

Cell viability $(\%)=(A t / A n) 100$

where At and An are the absorbance of samples for treated and normal cells, respectively.

\section{Assessment of photoluminescence}

The fluorescence spectrum of the ZnO NPs was analyzed to identify the emission bands and the transition between oxygen vacancies and interstitial oxygen $[15,16]$.

\section{Cytotoxicity assay}

MTT assays were performed using ZnO NPs on a HeLa cell line [17]. The HeLa cells were cultured in Eagle's minimum essential medium (MEM) containing $1 \%$ phosphate-buffered saline (PBS), $100 \mu \mathrm{g} / \mathrm{mL}$ penicillin, and $100 \mu \mathrm{g} / \mathrm{mL}$ streptomycin at 37 으. 3-(4,5-dimethyl-2thiazoyl)-2,5-diphenyltetrazolium bromide (MTT) assay was used to determine the cytotoxicity of ZnO NPs against cancer cell lines. The cancer 
cells were maintained in a humidified atmosphere of $50 \mathrm{mg} / \mathrm{mL} \mathrm{CO}_{2}$ at $37^{\circ} \mathrm{C}$. The cells were placed in 24-well plates. After an incubation period of $48 \mathrm{~h}$, the cells reached confluence. They were then incubated in various concentrations of $\mathrm{ZnO}$ NPs in $0.1 \%$ dimethyl sulfoxide (DMSO). The sample solution was removed and washed with PBS ( $\mathrm{pH} 7.4) 200$ IL/well $(5 \mathrm{mg} / \mathrm{mL})$ followed by addition of $0.5 \%$ MTT. After an incubation period of $48 \mathrm{~h}, 0.04 \mathrm{M}$ $\mathrm{HCl} /$ isopropanol was added. The proportion of remaining viable cells was determined using an ultraviolet-visible (UV-Vis) spectrophotometer to measure the absorbance at $570 \mathrm{~nm}$.

\section{RESULTS}

\section{XRD spectrum of ZnO NPs}

XRD results showed that $\mathrm{ZnO}$ NPs were present in wurtzite form, in agreement with the Joint

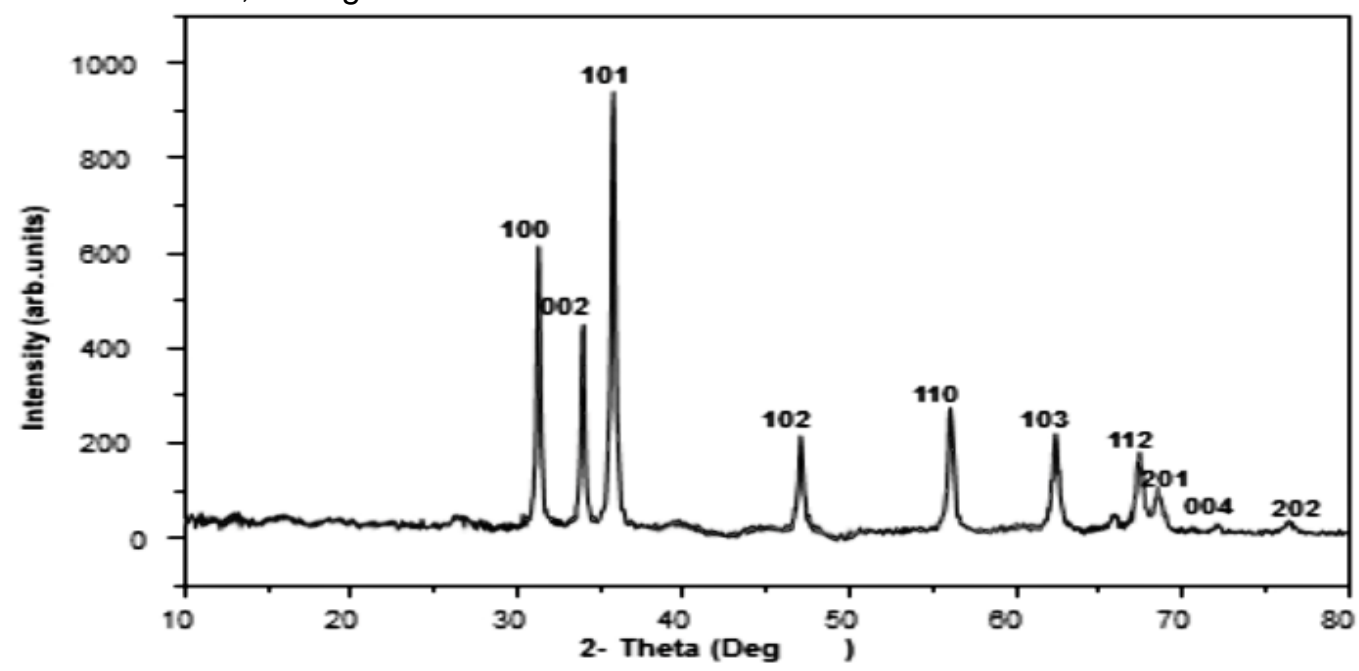

Figure 1: Zinc oxide nanoparticles (ZnO NPs) X-ray diffraction spectrum



Figure 2: Fourier transform infrared spectra of Tradescantia pallida aqueous leaf extract and ZnO NPs
Committee Powder Diffraction Standards (JCPDS) 89-7102 illustrated in Figure 1 [18-20]. The average size of the crystals was $25 \mathrm{~nm}$.

\section{FT-IR spectrum of the ZnO NPs}

The functional groups responsible for the conversion of metal precursors into metal NPs were identified using FT-IR analysis. The $\mathrm{ZnO}$ NPs were compared to TPALE. The peak at 1450-1500 $\mathrm{cm}^{-1}$ corresponds to $\mathrm{N}-\mathrm{H}$ stretching vibrations. $\mathrm{ZnO}$ NP stretching was identified at $400-800 \mathrm{~cm}^{-1}, \mathrm{O}-\mathrm{H}$ stretching at $3433 \mathrm{~cm}^{-1}$, and aldehyde $\mathrm{C}-\mathrm{H}$ stretching at $2934 \mathrm{~cm}^{-1}$. A protein peak was observed at $1250-1270 \mathrm{~cm}^{-1}$; thus, the ZnO NPs were covered with a layer of primary and secondary metabolites, i.e., proteins and functional groups, as illustrated in Figure 2 [21]. 


\section{Morphological and EDAX analysis}

Morphological analyses were performed using SEM and TEM to identify the size and structure of the TPALE-mediated synthesized ZnO NPs. The resulting agglomerated particles were rodshaped and had a size of $25 \pm 2 \mathrm{~nm}$, as illustrated in (Figure 3A-D). The EDAX spectrum shows that $\mathrm{Zn}$ and $\mathrm{O}$ were present in proportions of $83 \%$ and $17 \%$ respectively, as shown in Figure 4.

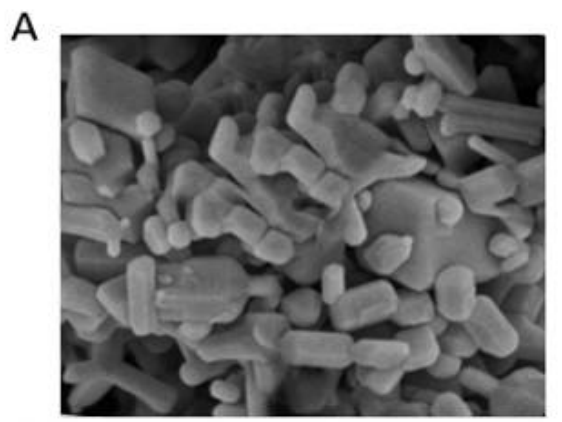

C

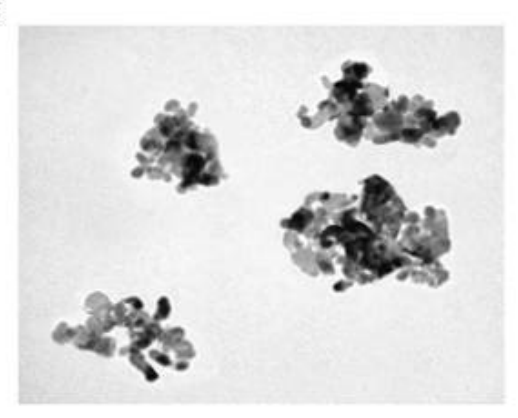

\section{Photoluminescence of ZnO NPs}

Fluorescence spectroscopy results of the $\mathrm{ZnO}$ NPs showed three color bands, namely, red, blue and green. Absorbance occurred at 447, 402, and $469 \mathrm{~nm}$, corresponding to the blue bands, and $483 \mathrm{~nm}$ corresponding to the green band. The blue bands were caused by defects in the $\mathrm{ZnO}$ crystals, and the green band was caused by the oxygen transition vacancy, as shown in Figure 5. [22,23].
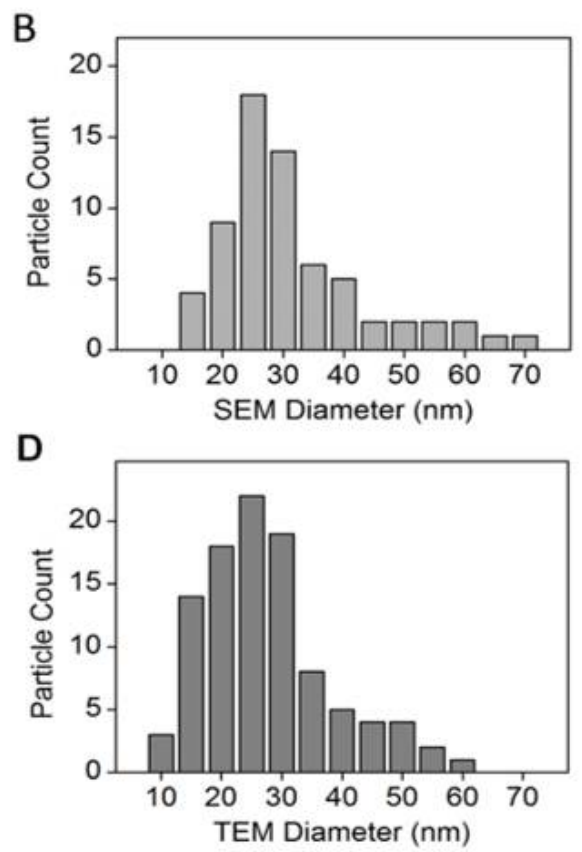

Figure 3: (A) ZnO NP scanning electron microscopy (SEM) image, (B) ZnO (SEM) particle size histogram, (C) ZnO NP transmission electron microscopy (TEM) image, and (D) ZnO NP (TEM) particle size histogram

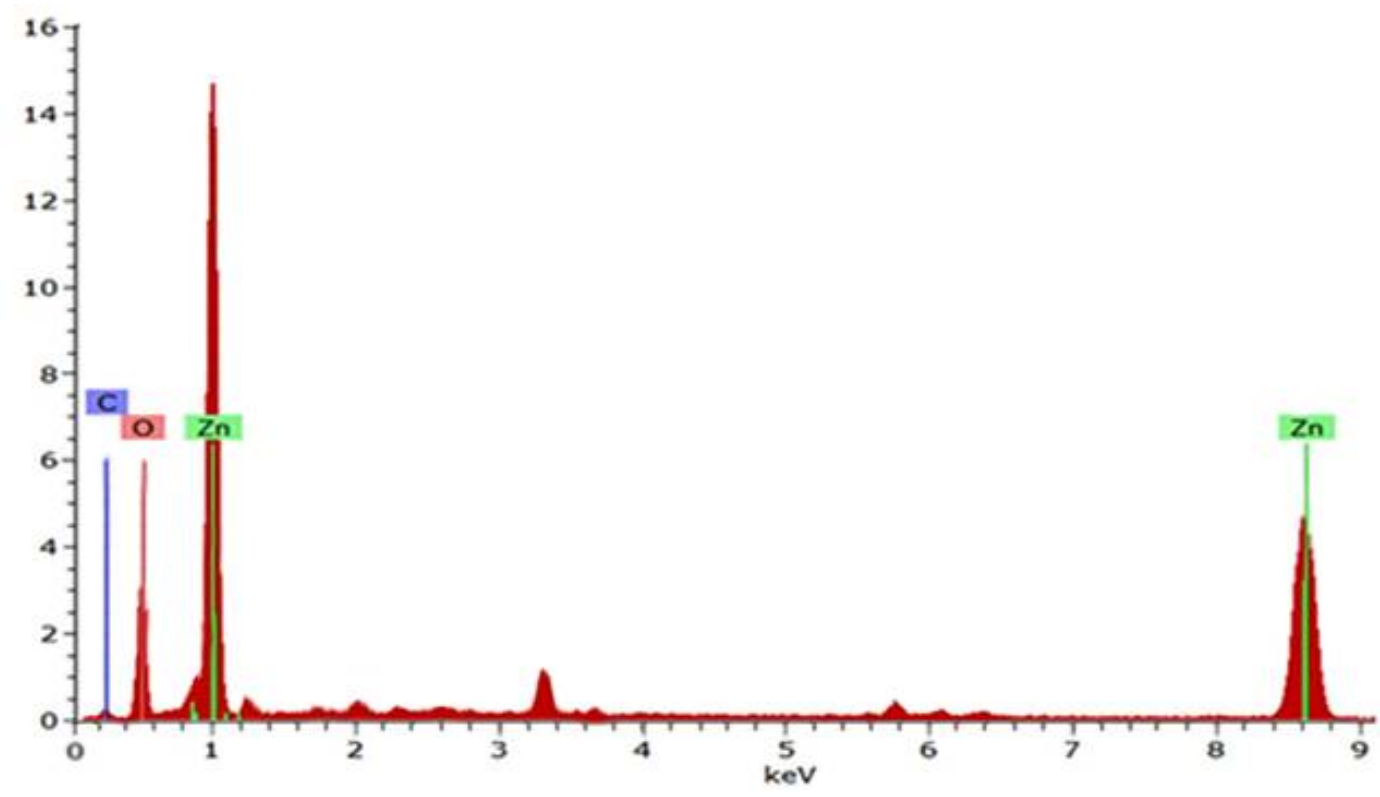

Figure 4: Energy dispersive X-ray analysis of ZnO NPs 




Figure 5: Photoluminescence spectrum of ZnO NPs

\section{Cytotoxicity activity}

The cytotoxicity assay results showed that 98.9 $\%$ of the cancer cells died after being subjected to a high dose $1000 \mu \mathrm{g} / \mathrm{mL}$ of $\mathrm{ZnO}$ NPs. We determined the concentration required for $50 \%$ inhibition of viability $\left(\mathrm{IC}_{50}\right)$ graphically. The $\mathrm{IC}_{50}$ of $\mathrm{ZnO} \mathrm{NPs} \mathrm{was} 62.5 \mu \mathrm{g} / \mathrm{mL}$ for the HeLa cervical cancer cell line. Cells from the HeLa cell line were treated with various concentrations of $\mathrm{ZnO}$ NPs for $48 \mathrm{~h}$. UV-visible spectroscopy was used to determine the proportion of live cells. The absorbance peak at $570 \mathrm{~nm}$ is clearly shown in Figure 6 [18].



Figure 6: Methyl thiazolyldiphenyl-tetrazolium bromide assay against HeLa cell line

\section{DISCUSSION}

There has been great interest in NP synthesis based on plants, as there are several drawbacks to physical- and chemical-mediated NP synthesis. TPALE has not been used previously to synthesize NPs. Here, we synthesized ZnO NPs using TPALE and conducted cytotoxicity tests against HeLa cells. The ZnO NPs had a size of $25 \mathrm{~nm}$ and an agglomerated rod shape.

The present results indicate that TPALEmediated ZnO NPs are toxic to HeLa cells, killing $98.9 \%$ of the cancer cells when a high dose of $1000 \mu \mathrm{g} / \mathrm{mL}$ was used. The concentration required for $\mathrm{IC}_{50}$, determined via graphic interpolation, was $62.5 \mu \mathrm{g} / \mathrm{mL}$ for the HeLa cervical cancer cell line. There are several existing reports detailing the green synthesis of ZnO NPs from plant sources. These sources include Citrus aurantifolia peel, which resulted in prism-shaped particles with an average size of $35 \mathrm{~nm}$ [24], Vitex negundo L. extract, Caralluma fimbriata, and Euphorbia Jatropa latex $[25,26]$; however, few reports detail cytotoxicity assay and photoluminescence investigations of greensynthesized $\mathrm{ZnO}$ NPs. In future studies, it is intended that a simpler method to synthesize ZnO NPs will be developed. Such a method would serve as a reference for researchers to develop other methods to ecologically synthesize metal NPs for potential application as treatments for various medical disorders.

\section{CONCLUSION}

A simple approach for $\mathrm{ZnO}$ NP synthesis based on TPALE has been developed successfully. The mean particle size of the ZnO NPs was $25 \mathrm{~nm}$, and the final product consisted of agglomerated rod-shaped particles. The synthesized nanoparticles demonstrate good luminescence properties. Cytotoxicity results against cervical cancer lines indicate $98.9 \%$ of cancer cells died 
after exposure to a dose of $1000 \mu \mathrm{g} / \mathrm{mL} \mathrm{ZnO}$ NPs.

\section{DECLARATIONS}

\section{Acknowledgement}

The authors acknowledge the funds and lab facilities provided for this research by the 117th Hospital of the Chinese People's Liberation Army, Hang Zhou.

\section{Conflict of Interest}

No conflict of interest associated with this work.

\section{Contribution of Authors}

The authors declare that this work was done by the authors named in this article and all liabilities pertaining to claims relating to the content of this article will be borne by them.

\section{Open Access}

This is an Open Access article that uses a funding model which does not charge readers or their institutions for access and distributed under the terms of the Creative Commons Attribution License (http://creativecommons.org/licenses/by 14.0) and the Budapest Open Access Initiative (http://www.budapestopenaccessinitiative.org/rea d), which permit unrestricted use, distribution, and reproduction in any medium, provided the original work is properly credited.

\section{REFERENCES}

1. Elumalai $K$, Velmurugan $S$, Ravi $S$, Kathiravan $V$, Ashokkumar S. Green synthesis of zinc oxide nanoparticles using Moringa oleifera leaf extract and evaluation of its antimicrobial activity. Spetrochim. Acta A 2015; 143: 158-164.

2. Suresh D, Nethravathi PC, Udhayabanu, Rajanaika $H$, Nagabushana $H$, Sharma SC. Green synthesis of multifunctional zinc oxide ( $\mathrm{nnO}$ ) nanoparticles using Cassia fistula plant extract and their photodegradative, antioxidant and antibacterial activities. Mater. Sci. Semicond. Proces 2015; 31: 446-454.

3. Camelia CHIMPAN, Monica SIPOS. Anatomy of the vegetative organs of Tradescantia pallida purpurea. Biharean Biol 2009; 3: 1-4.

4. Paiva EAS, Santos Isaias RM, Vale FHA, Senna-Queiroz $C G$. The influence of light intensity on anatomical structure and pigment contents of Tradescantia pallida (Rose) Hunt. cv. purpurea Boom (Commelinaceae) leaves. Braz Archiv Biol Tech 2003; 46: 617-624.
5. Schilling K, Bradford B, Castelli D, Dufour E, Nash JF, Pape W, Schulte S, Tooley I, van den Bosch J, Schellauf F. Human safety review of "nano" titanium dioxide and zinc oxide. Photochem Photobiol Sci 2015; 9: 495-509.

6. Gerloff K, Fenoglio E, Carella I, Kolling J, Albercht C, Boots A, Forster I, Schins RP. Distinctive toxicity of TiO2 rutile/anatase mixed phase nanoparticles on Caco-2 cells. Chem Res Toxicol 2012; 25: 646-655.

7. Jin T, Sun D, Su JY, Zhang $H$, Sue HJ. Antimicrobial efficacy of zinc oxide quantum dots against Listeria monocytogenes, Salmonella Enteritidis, and Escherichia coli 0157:H7. J Food Sci 2009; 74: 46-52.

8. He L, Liu Y, Mustapha A, Lin M. Antifungal activity of zinc oxide nanoparticles against Botrytis cinerea and Penicillium expansum. Microbiol Res 2011; 166: 207215.

9. Abdul SH, Sivaraj R, Venckatesh R. Green synthesis and characterization of zinc oxide nanoparticles from ocimum basilicum l. var. Purpurascens benth.lamiaceae leaf extract. Mater Lett 2014; 13: 16-18.

10. Prabakar K, Kim H. Growth control of ZnO nanorod density by solegel method. Thin Solid Films 2010; 518: 136-138.

11. Ramesh M, Anubuvannan M, Viruthagiri G. Green synthesis of ZnO nanoparticles using Solanum nigrum leaf extract and their antibacterial activity. Spectrochim Acta $A$ 2015; 136: 864-870.

12. Bai $H$, Liu $X$. Green hydrothermal synthesis and photoluminescence property of $\mathrm{ZnO} 2$ nanoparticles. Mater Lett 2010; 64: 341-343.

13. Christine SS, Ingo S, Peter S, Uwe K, Heinz-Peter S, Dirk L. Mitochondrial haplogroups and expression studies of commonly used human cell lines. Mitochondrion 2016; 30: $236-247$.

14. Lokina S, Suresh R, Giribabu K, Stephen A, Lakshmi Sundaram $R, \quad$ Narayanan $V \quad$ Spectroscopic investigations, antimicrobial, and cytotoxic activity of green synthesized gold nanoparticles Spectrochim. Acta A 2014; 129: 484-490.

15. Johan MR, Chong LC, Hamizi NA. Bayesian Neural Networks Model for lonic Conductivity of Nanocomposite Solid Polymer Electrolyte System (PEO - LiCF3SO3 - DBP - ZrO2) 2012; 7: 4567-4573.

16. Huang J, Yu P, Yuan CT, Ko HC, Tang J, Hseih TS. Single-particle studies of the plasmonic fluorescence in gold nanocubes. J Nanophotonics 2012; 6: 1-6.

17. Lokina S, Suresh R, Giribabu K, Stephen A, Lakshmi RS, Narayanan $V$. Spectroscopic investigations, antimicrobial, and cytotoxic activity of green synthesized gold nanoparticles. Spectrochim Acta A 2014; 129: 484490.

18. Sangeetha G, Rajeshwari S, Venckatesh R. Green synthesis of zinc oxide nanoparticles by aloe barbadensis miller leaf extract: Structure and optical properties. Materials Research Bulletin 2011; 46: 25602566. 
19. Dutta RK, Nenavathu BP, Gangishetty MK, Reddy AV. Studies on antibacterial activity of $\mathrm{ZnO}$ nanoparticles by ROS induced lipid peroxidation. Colloid Surf B 2012; 94: 143-150.

20. Goldsmith JA, Ross SD. Factors affecting the infra-red spectra of planar anions with D3h symmetry-ll The intensity of $v 1$ in some simple, basic and complex carbonates. Spectrochim Acta 1966; 22: 1069-1072.

21. Vanheusden $K$, Warren WL, Seager $C H$, Tallant $D R$, Voigt JA, Gnade BE. Mechanisms behind green photoluminescence in $\mathrm{ZnO}$ phosphor powders. Appl Phys 1996; 79: 79-83.

22. Shim ES, Kang HS, Pang SS, Kang JS, Yun I, Lee SY. Annealing effect on the structural and optical properties of ZnO thin film on InP. Mater Sci Engg B 2003; 102: 366-369.

23. Nagajyothi PC, MinhAn TN, Sreekanth TVM, Lee J, Lee $D J$, Lee KD. Green route biosynthesis: Characterization and catalytic activity of $\mathrm{ZnO}$ nanoparticles. Mater Lett 2013; 108: 160-163.

24. Ambika S, Sundararajan M. Green biosynthesis of ZnO nanoparticles using Vitex negundo $L$. extract: Spectroscopic investigation of interaction between $\mathrm{ZnO}$ nanoparticles and human serum albumin. $J$ Photochem Photobiol B 2015; 149: 143-148.

25. Mishra $P$, Singh YP, Nagaswarupa HP, Sharma SC, Vidya YS, Prashantha SC, Nagabhushana $H$, Ananatharaju KS, Sharma S, Renuka L. Caralluma fimbriata extract induced green synthesis, structural, optical and photocatalytic properties of $\mathrm{ZnO}$ nanostructure modified with Gd. J Alloy Comp 2016; 685: 656-669.

26. Geetha MS, Nagabhushana H, Shivananjaiah HN. Green mediated synthesis and characterization of $\mathrm{ZnO}$ nanoparticles using Euphorbia Jatropa latex as reducing agent. J Sci Adv Mater Dev 2016; 1: 301-310. 